\title{
Diffusion of operational capabilities knowledge: The social skills perspective
}

\author{
Cristiane Biazzin ${ }^{\mathrm{a}}$ (D), Mario Sacomano Neto ${ }^{\mathrm{b} *}$ (D), Silvio Eduardo Alvarez Candido ${ }^{\mathrm{b}}$ \\ aNorthern Kentucky University, Kentucky, United States \\ bUniversidade Federal de São Carlos, São Carlos, SP, Brasil \\ *sacomanoneto@gmail.com
}

\begin{abstract}
Paper aims: This paper aims to understand how the social skill of managers influence the diffusion of operational capabilities in food and auto parts manufacturing networks.

Originality: There are taken-for-granted beliefs that its diffusion is based on replicating or transferring resources and practices from one site to another. This study is one of the first ones to discuss operational capability and socially skilled actors.
\end{abstract}

Research method: Two polar cases were analyzed through the Strategic Action Fields perspective based on a qualitative perspective and 17 in-depth interviews.

Main findings: Results demonstrate that diffusion of capability among various actors in subsidiaries will depend on a series of multidimensional factors that influence this process as the stability, state, and relationship between fields. Moreover, members tend to adopt a logic (perception of the world) that reflects the point of view of the group, and from this, the actors construct their narratives, recognize the legitimacy and justify their actions.

Implications for theory and practice: These perspectives have scarcely been explored in Operations management till today and shall open a new dialogue between Operations Strategy and Organization Studies. It offers practical guidance for diffusing and deploying operational capabilities.

Keywords:

Operational capabilities. Operations. Strategy. Fields and social skills.

How to cite this article: Biazzin, C., Sacomano Neto, M., Candido, S. E. A. (2020). Diffusion of operational capabilities knowledge: the social skills perspective. Production, 30, e20200015. https://doi.org/10.1590/0103-6513.20200015.

Received: Feb. 12, 2020; Accepted: July 2, 2020.

\section{Introduction}

Contemporary management literature indicates that superior performance can be linked to the fact that two or more organizations together can create more value than one unit in isolation (Tsai \& Ghoshal, 1998; Björkman et al., 2007; Lindgreen et al., 2012, Spring et al., 2017). Operational capabilities have been seen as a fundamental basis for activities to excel (Peng et al., 2008; Wu et al., 2010). From an intra-organizational perspective, the possibility of diffusion of an operational capability developed in one unit to another (Ambos et al., 2006) reveals the organizational actors' skills in creating and providing value faster (Lindgreen et al., 2012) and establish competitive advantages (Prahalad \& Hamel, 1990; Ciabuschi et al., 2017).

The operational capability is wilfully built (Flynn et al., 2010), and its diffusion is supposed to be organized and deliberated. It is driven by individual expertise (Flynn et al., 2010) and disseminated through relationships and ties established by individuals from different sites (Schoenherr \& Narasimhan, 2012; Ranft \& Lord, 2002; Björkman et al., 2007). However, different business units should have different roles, and, consequently, create different implementation requirements (Lin \& Hsieh, 2010), and outcomes (Ferdows, 2012) to deploy operations 
strategy. Organizations are also subject to different levels of uncertainty in their environments, which can rapidly transform the foundations of competition (Menor et al., 2007). Moreover, capabilities deployment seems to be much more complicated than merely replicating and imitating practices and routines (Winter \& Szulanski, 2001), or transferring resources and technology from one site to another. The success of this process depends on a series of multidimensional factors (Sako, 2004; Biazzin et al., 2020), ranging from how the organization accesses and incorporates the knowledge acquired with its collaborators (Kogut \& Zander, 1992; Nonaka, 1994; Grant, 1996; 2000; Norman, 2004; Jacobides \& Winter, 2005; Ambos et al., 2006; Van Wijk et al., 2008; Ritala et al., 2015), the rigor of practices and the experience accumulated over time (Zander \& Kogut, 1995) and diverse institutional logics (Olsen \& Solstad, 2017).

Much of the literature focused on understanding the formation and diffusion of capabilities rests on rational or functional assumptions of human behavior in organizations (Martin, 2003; Emirbayer, 1997). Culture has been acknowledged as a vital factor of capabilities (Jones et al., 2005; Peng et al., 2008;), and few studies address the processes through which this influence tends to occur.

This study asserts that the diffusion of capabilities depends on socially skilled managers (Fligstein \& McAdam, 2012), which establish the foundations for a firm to create and provide value for its partners and value chain members (Lindgreen et al., 2012). A capability is established when actors in the organization can build a shared understanding regarding the operations, defining well established social arrangements. The process leading to this consensus is not trivial and unproblematic, as is usually assumed in the literature. It is because actors involved in the operation have varied interpretations and interests regarding the operational situations (Amason et al., 1995; Katsikopoulos \& Gigerenzer, 2013; Candido et al., 2017). The forging of common understanding may involve relations of influence in the context of achieving adaptation and change (Muchiri et al., 2019), and it is crucial to adopt perspectives able to address how these processes unfold.

The paper explores the specific role of social skilled actors (Fligstein, 2001) in fashioning the meaningful arrangements on which capabilities derive. The concept of social skills considers the actors through the interaction with other members of a field, their development of values, meaning, identity, and creation of a positive vision of their assumptions, bringing sense to the narratives adopted by the individuals (Fligstein, 2001). However, even the strategic actors, in working to advance their interests, are simultaneously exercising their capacity to make sense of and construct a collective identity for the other members (Fligstein \& McAdam, 2012). Social skills involve cognitive, empathic, and communicative skills to ensure cooperation. There are also studies on human capacity and the need to establish common meanings and identities capable of securing an existential basis (Fligstein \& McAdam, 2012).

The following research questions emerge to overcome hurdles that arise while disseminating a capability: How do socially skilled actors contribute to the diffusion of operational capabilities among intra-organizational units? For this purpose, it explores how the social skills support the maintenance of order and the extent of the logics that sustain the actors' narratives that can impact operational capabilities diffusion. The paper aims to contribute to a broader understanding of operational capabilities, emphasizing the social processes that form the basis of its operation. It is argued that socially skilled actors create shared meanings based on forms of justification for their views of the common good (Boltanski \& Thevenot, 1999; 2006). In doing so, they use culture (Swidler, 1986) to establish shared meanings based on which the actors involved the operating coordinate their actions.

The analytical perspective proposed by this study is founded on the Strategic Action Fields approach (Fligstein, 1990; 2001; 2013; Fligstein \& McAdam, 2012), which is cross-fertilized with insights from the Sociology of the Action Regimes (Boltanski \& Thevenot, 1999; 2006) and Social Psychology (Jost \& Hunyady, 2005).

\section{Literature Review}

\subsection{The Role of Operational Capabilities knowledge}

Operations managers are facing critical challenges. Companies are struggled to be able to customize, improve and innovate process to attend uniqueness needs, reshape operations resources and react quickly to catch up with market changes and bring involved parties together to share information converging on a sharing interpretation of what is needed to be done. These operational capabilities are considered a holy grail for competitive advantage (Wu et al., 2010). However, the operational capability is a strength (Peng et al., 2008) constructed deliberately (Flynn et al., 2010) from the firm's resources (Pavlou \& El Sawy, 2011) and oriented to accomplish a specific aim (Amit \& Schoemaker, 1993) and it takes time. lt may be understood as a complex set of skills and knowledge, accumulated over time, that favor company control and coordination of activities, and making the best use of 
its assets (Grössler \& Grübner, 2006). It seizes previous technical and marketing knowledge through voluntary choices. Thus, control and coordination become ends and not necessarily means (Katz \& Kahn, 1978).

As it takes time, the company who can speed up the pace to assimilate the capability learned from one unit to another, will be able to get significant outcomes (Helfat \& Winter, 2011). However, the operational capabilities are specific to the firm (not to the individuals that belong to it). Individuals may be highly qualified and possess specific knowledge, but they may have difficulties in passing on this knowledge or replicating it in another place (Kogut \& Zander, 1992). One may highlight the idea of complexity in the construction of the operational capabilities because of the interactions among the firm's resources, based on tangible or non-tangible resources (Amit \& Schoemaker, 1993). In general, when the market is stable, and an economy of scale dominates, the more connections there are among the units, the more efficient the process may be (Eisenhardt \& Galunic, 2000).

In an organization with multiple units spread out geographically, there is a considerable benefit if this group of companies can teach and learn from each other (Tsai, 2002). Not only constrained to the exchange of practices but the process of mature operational capabilities, values, and knowledge developed within the intra-organizational network (Ferdows, 2012).

When the market becomes dynamic, and agility begins to exert a more considerable influence on the business, fewer connections are demanded to adapt to new scenarios swiftly. To maintain their sustainability, organizations use control and coordination as ends and not necessarily as a means. These same forces may be transformed into the principal hindrance to the diffusion of a capability in an intra-organizational network. Political and cultural aspects emerge as a possible influence on capability configuration, diffusion, and change. It becomes necessary to understand how the groups of actors dispute resources and how social relations and interactions could influence information sharing and legitimacy. In this sense, due to the critical social and individual influence on capability development, it seems convenient to amplify the analysis of operational capabilities diffusion by addressing the dynamics of strategic action fields.

\subsection{The strategic action fields and social skills}

Field theories have been increasingly influential in organization studies as they represent an alternative to both rational individualist and functionalist perspectives (Martin, 2003; Candido et al., 2018). While the approach is in line with the interpretative paradigm of the study of organizations, which claims that the social sciences deal with phenomena that are subjective and open to interpretation (Morgan, 2005), it recognizes, in line with Durkheim (2002) idea of social fact, that widely shared interpretations about certain aspects may get "naturalized" in the multiple instances of social life, becoming objectified. This objectification occurs via the establishment of local conventions that are followed unreflexively by individuals, enabling their cooperation and the smooth operation of organizations.

Field theories also systematically consider the influence of individuals in the establishment of organizational arrangements. In doing so, it assumes that individuals are heterogeneous. As people have different life histories, they tend to interpret the world surrounding them in different ways, and according to different social conventions. However, to collaborate, they must come into terms and adopt shared references and conventions. Otherwise, they will not be able to coordinate their actions and to operate functionally (Boltanski \& Thévenot, 2006). The definition of these shared references that enable collective action entails power relations. While in specific field theories, power relations are viewed in a negative vein, the strategic action field approach emphasizes the positive character of power as a facilitator of cooperation (Candido et al., 2018). In this sense, fields can be defined as "a social arena, where something is at stake and actors come to engage in social action with other actors under a set of common understandings and with a set of resources that help define the social positions in the field" (Fligstein, 2013, p.41).

Organizations are kinds of fields with formally defined boundaries and hierarchical structures, which facilitates coordination (Fligstein \& McAdam, 2012). They are internally differentiated, being composed by multiple internal subfields, as "Russian doll” (Fligstein \& McAdam, 2012). Nevertheless, organizational power relations may never be wholly reduced to formal power relations. As top managers are themselves heterogeneous and compose subfields with different interests or points of view (operational, commercial, financial, etc.), field approaches suggest that making sense of the conflicts of these organizational elites is vital to understand organizational dynamics (Bourdieu, 2005). While having an essential role in arbitrage conflicts and in creating compromises between these areas, the professional trajectories and academic backgrounds of CEOs themselves, which are more aligned to specific subfields (Fligstein, 1987), matter. The CEOs and other top executives also interpret their environment. They tend to imitate management practices that they consider to be successful, which are imposed by powerful actors of their environment or which are popularized as "rational myths" (Meyer \& 
Rowan, 1977) by business schools (DiMaggio \& Powell, 1983). As a result of both, the interpretation of their environment and the dynamic of intraorganizational power relations, top managers fashion and put forward certain conceptions of control (Fligstein, 1990) or models of management (Guillén, 1994) that give a certain coherence to organizational operation.

The strategic action fields approach claims that, besides power differentials, the construction stable and functional organizations depend on the social skills of actors (Fligstein, 2001; Fligstein \& McAdam, 2012). Social skills are the abilities to induce cooperation among others and socially skilled actors

“[...] must understand how the sets of actors in their group view their multiple conceptions of interest and identity and how those in external groups do as well. They use this understanding in particular situations to provide an interpretation of the situation and frame courses of action that appeal to existing interests and identities." (Fligstein, 2001, p. 112).

While all human beings have social skills, some are more skilled than others. This capacity of interact emphatically is independent of power, and the formal positions of authority actors occupy, and social skills may amplify the power organizational elites have to coordinate many individuals.

Social skilled actors can create stories and narratives that appeal to others by relating to their identities and interests and frame actions against common opponents (Fligstein, 2001). The fashioning of a conception of control is one of such stories capable of mobilizing and guiding organizational members' behaviours (Fligstein, 1990). For these stories to be compelling, they must have a collective appeal instead of appealing to self-interested forms of reasoning.

The strategic action fields suggest that the main challenge for a firm to succeed in the construction of a social order capable of stabilizing social relations and enable cooperation and functionality. While specific organizational arrangements may be more intrinsically more efficient than others, commonly, the leading challenge organizations face is finding a stable social arrangement that works as a foundation for organizational capabilities. As the capability's literature emphasizes, the strategic action field approach suggests that these social arrangements are unique, since they depend on a set of singular individuals that pertain to an organization. As enablers of cooperation, influential and socially skilled actors have a crucial role in building the social arrangements that lead to operational capabilities.

Different units of a firm have their specific social arrangements and may have different capabilities. However, to the degree they are integrated into a single organizational structure, these different forms of operation may compete and jeopardize the overall operation of a firm. In this sense, a firm needs to disseminate specific operational capabilities among units to promote the cooperation of the organization as a whole. To do so, top managers must use their power and social skills to somehow transpose the social ordering of one unit to the other.

\section{Research methodology}

This research aims to exploit how the logics that sustain the actors' narratives can impact operational capabilities diffusion, and the outcomes can be useful for practitioners' reasoning and scholar testing purposes. The researchers adopted a qualitative approach based on two polar-extreme cases (Barratt et al., 2011). The authors selected purposive two comparable cases before data collection (Miles et al., 2014): they choose one organization that has been disseminating operational capabilities within their network and another organization that has been facing difficulties to deploy operational capabilities within their network. The names of the organizations and their staff are kept in confidence at the request of the respondents. All data and the content of the interviews remained unaltered and were analyzed in full detail. The criteria for ensuring the internal validity, rigor, and benefits of the case study were carefully followed in this work (Eisenhardt, 1989; Dyer Junior \& Wilkins, 1991; Meredith, 1998; Miles et al., 2014).

\subsection{Data collection}

Semi-structured, in-depth interviews (Dyer Junior \& Wilkins, 1991; Rowley, 2012; Miles et al., 2014) were based on a review of the literature and made provision for devising open questions in such a manner that the interviewee would have the possibility of expressing and arguing his point of view, his experience, and his vision of the concepts and dynamics presented (Rowley, 2012). The research instrument is shown in Appendix A. To build a final sampling database for interviews, the authors selected and contacted respondents based on the snowball technique (Miles et al., 2014). 
The study concentrated on observing the different hierarchical levels in each organization: (1) Top management; (2) Middle management that experiences the day-to-day reflections of the operational capabilities; (3) Team directly involved in training and diffusion of these capabilities among the units. This study is based on 17 in-depth interviews (as detailed in Table 1). The interviews last between 50 to 110 minutes, were recorded and transcribed. Besides, the researchers collect information from documents, statements of the organization on the Internet, and articles in business publications (Miles et al., 2014), and they also adopted direct, non-participative observation (Angrosino \& Rosenberg, 2011) to observe the group dynamics.

Table 1. Respondents list.

\begin{tabular}{cc}
\hline Company A & Company B \\
\hline CEO & Latam Business Director \\
Production Manager & Project Manager 1 \\
Quality Manager & Project Manager 2 \\
HR Manager & Engineering Manager \\
Industrial Director & Quality Manager \\
Plant Manager 1 & Plant Manager \\
Plant Manager 2 & Lean Manufacturing and Excellence Manager \\
Continuous lmprovement Manager & \\
Engineering Manager & \\
RandD and Innovation Manager &
\end{tabular}

Source: authors.

\subsection{Data analysis}

We explore the data by first evaluating individual interviews and cases (within-case analysis). Then, we developed the case description based on the interview transcripts, secondary data collection, and field observation (notes taken by researchers). Additionally, we made a supreme effort to identify evidence of the group and individual worth to address the correct classification and, consequently, the proper analysis. By doing so, we code the data (Miles et al., 2014) based on the following theoretical elements: state of the field and field stability (Fligstein \& McAdam, 2012), higher common principles, the state of worthiness, the relation of worth (Boltanski \& Thevenot, 2006), power and control mechanisms (Maloni \& Benton, 2000; Crook \& Combs, 2007) and the relationship between members (Fligstein \& McAdam, 2012). Those elements offered substantial resources for building the cross-case analysis (Table 2). Moreover, we evaluated the data separately and discussed each piece of evidence to validate our findings (Silverman, 2006). Then, we advanced further to a cross-case analysis of both organizations' dynamics following Miles et al. (2014). By doing so, our data analysis was an iterative process of literature and empirical results. We also make sure our inferences are tightly aligned with interviews, and they summarized the core inferences with excerpts from respondents in Table 2.

Table 2. Cross-case Analysis.

\begin{tabular}{|c|c|c|}
\hline & Evidence & Evidence \\
\hline & Case A & Case B \\
\hline Field stability & $\begin{array}{l}\text { Indifference over any positive movement of other fields. } \\
\text { "[...] our plant is unique. I do not believe it could be feasible } \\
\text { to share anything with another unit. They have their way of } \\
\text { working, which l do not trust at all. I do prefer to run the } \\
\text { shop floor as we have been doing for a long time."* }\end{array}$ & $\begin{array}{l}\text { We are continually looking for benchmarking other fields' } \\
\text { best practices. Evidence of mimetic behavior. } \\
\text { "I realize that we have several weaknesses here, and l've } \\
\text { been pushing my team to be closer to other sites, try to } \\
\text { grasp how they solve common issues. l am sure that we } \\
\text { could learn a lot from others' experiences, even considering } \\
\text { that the Brazilian environment is quite different anyway" }\end{array}$ \\
\hline $\begin{array}{l}\text { Higher common } \\
\text { principle }\end{array}$ & $\begin{array}{l}\text { Be public, recognition and self-love "Partnership with a } \\
\text { university would be nice for the company image." } \\
\text { "[...] we are recognized as the first choice of our customers } \\
\text { in the sweets and snacks market. Even considering that some } \\
\text { customers start enquiring about China as a new supplier, we } \\
\text { do not believe there would be a gap shortly."* }\end{array}$ & $\begin{array}{l}\text { Best in class, look for process improvement continuously, } \\
\text { things under control, efficiency } \\
\text { "[...] Things are very homogeneous among the factories, as } \\
\text { what you see here you will see in anyone. The organization } \\
\text { you see here, you will see outside in any unit. It's the same } \\
\text { picture, the same way of doing things everywhere."* }\end{array}$ \\
\hline $\begin{array}{l}\text { System Dependence } \\
\text { Level }\end{array}$ & $\begin{array}{l}\text { Resistant to any threat the field may suffer, they do not } \\
\text { verbalize criticism of their field, but that of the others. } \\
\text { On the contrary, they have a self-image as a reliable } \\
\text { organization. The defensibility of the status quo is limited. } \\
\text { "The management of unit X is trying to copy the way } \\
\text { we are doing things here. It shows how weak they are. } \\
\text { Top management realized it as well. } 1 \text { think it is a bad thing, } \\
\text { as they do not have the same expertise as we do." }\end{array}$ & $\begin{array}{l}\text { Actors rely on the organization for the trajectory, origin, and } \\
\text { previous successes. They respect the rules. Nevertheless, they } \\
\text { realize that they have low individual control over the system, } \\
\text { and even though on some occasions, the actors disagree } \\
\text { with the decisions taken, they follow them. "[...] Germany } \\
\text { (the Headquarter) does not accept any change without its } \\
\text { previous approval. We cannot do anything by ourselves. } \\
\text { And that's OK."* }\end{array}$ \\
\hline
\end{tabular}

Source: Developed by the authors; Note: *italic statements are excerpts from respondents' narratives during interviews. 
Table 2. Continued...

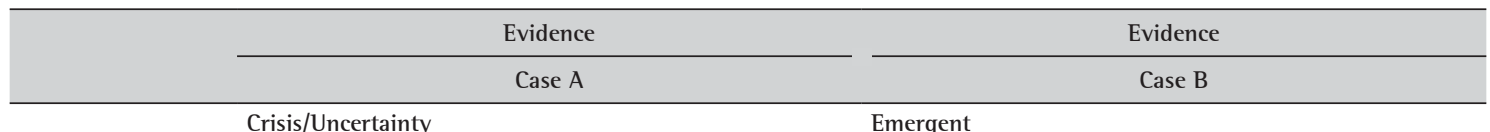

All decisions are taken at the unit level. There is no clear operations strategy for the entire organization. Internal misalignment - managers do not recognize competition (managers do not perceive, e.g., Chinese entry into local market impacting status quo). Plant rivalry, each unit was protecting its knowledge and resources from the others. "Each plant has its way to manage the operations. It brings State of field flexibility and self-sufficiency to the plant manager to solve problems. It doesn't make any sense to standardize the process. We will lose all the efforts we made in the past if we do it. It does not make sense."

"[...] we heard some customers have been buying from Chinese factories. It seems to be a fashion, in my opinion. China has similar good products, but 1 don't think they would impact strongly on our market. Our customers will perceive that it is not worth transporting candies from China to Brazil. They know our brand is well established"*

All decisions are made in HQ (Germany). HQ has control over all the unit/ plant network resources, and it influences the market as a whole.

\section{State of worthiness Singular reputation, recognition, visibility}

\section{Relation of worth,} power and control mechanisms

Relationship between fields 1dentification, strength

Indifference, there is a rare exploration of knowledge-sharing by actors. There is a critical team in charge of continuous improvement. However, plant managers are not motivated enough to share experiences.
Reliability, standardization of process, and behavior.

"[...] Things are very homogeneous among the factories, as what you see here, you will see in anyone. The organization you see here, you will see outside in any unit. It's the same picture, the same way of doing things everywhere."*

Hierarchical control

Openness, the organization encourages teams to talk, creation of forums and global meetings for discussing best practices and moving forward.

Source: Developed by the authors; Note: *italic statements are excerpts from respondents' narratives during interviews.

\section{Results}

\subsection{Operational capabilities Knowledge: within-case analysis.}

\subsubsection{Case A - Food sector}

Company A is a food products manufacturing company, founded in 1967 in Brazil. The company has three units: two located in São Paulo and a third located in Paraná (Brazil). 1ts main products are sweets and salted snacks. The plants it owns come from acquisitions made in the 1980s and 1990s. Each unit has retained its characteristics, and little effort has been made to seek possible standardization among the different units. In mid-2010, the patriarch of the family left the leadership of the organization, passing management to the second generation.

The organization then decided to restructure its operations and hired a former production manager from a renowned multinational in the food industry, recognized for its operational excellence. The manager has sought to restructure the operation gradually. However, the direction of top management has not been clear; the organization is immersed in unstructured, informal relationships, and has a low degree of governance over its processes. The influence of the top management also does not encourage the employees who work in the $\mathrm{HQ}$ to attend adequately and in the same proportion to the three units.

On the contrary, not only the employees but also the top management justify low performance with expressions of 'there is no control,' 'there it is anyway.' These expressions are part of the shared discourse of these executives when referring to other manufacturing units that are part of the network. As each unit has methods and operational routines established informally, the company has difficulty keeping up with the level of operational efficiency.

One can elucidate that each site of the organization has characteristics of a field: some socially skilled actors lead employees to similar mindsets, and the group tends to defend their manufacturing unit whenever compared 
to another unit. These actors identify themselves by working together for many years, never changing factory units, and have a history and a shared identity.

The first striking feature in members' speeches of this organization is their perception of the company's reputation. The organization has already been very famous in the market where it operates, and the members are proud of this. Also, the senior leadership always emphasizes being the best, being in the media, being part of the primary decision-makers in the industry. These actors have a self-image of the "best in the market" and do not recognize the need for changes stemming from ideas generated in other manufacturing plants. There is an apparent competition among manufacturing units, strongly provoked by top management through comparative performance indicators and public retaliations when something negative occurs.

Consequently, the actors need to feel publicly recognized, an urge to stand out from the others. It was possible to perceive that from the firm's competitiveness, the actors are practically unaware of the possibility of new entrants jeopardizing their brands and their competitiveness in the market. The organization highlighted a set of actors that have easy access to the most diverse levels and delegate the task of promoting the integration and sharing of skills among the manufacturing units. Due to its more significant presence in other institutional environments, such as lectures, training, continuous improvement benchmarks, this group realizes that the organization's competitiveness has diminished significantly in the last few years. In addition to sharing best practices, the group has sought to highlight critical points of inefficiency, such as processes in some of the units with high levels of waste, and make significant efforts to develop skills. Nevertheless, such an effort is superficial most of the time. The actors in each of the fields tend to be highly resistant to any recommendation that comes from the improvement team or other units.

\subsubsection{Case B - Auto parts sector}

Case B is a German auto parts manufacturing company. The company employs about 30,000 employees in 170 units around the world. It has three main businesses: i) the division of tubes and rolled stocks; ii) the division of engineering services, with the development of projects in several sectors, such as automobile, infrastructure, industrial, and public transportation; and iii) the automotive division (object of this study), with the development and production of structural parts, chassis, modules, and engines. For the automotive division, Company B has 70 factories in 29 countries and employs 21,000 people. It develops joint product projects with the automakers; it is considered the first link in the supply chain (tier 1). One of the hallmarks of this organization is process care and the emphasis on standardization. Possibly linked to the German origin of the company and because it is a family business, the zeal for the quality of products and services at all levels of the organization is perceived. No adjustments or changes to these procedures are allowed before HQ discussions have taken place, and permission is granted. The tradition of brand and products is a source of pride for members.

In this way, it is perceived that the HQ supports the establishment of practices and routines unilaterally, and it influences the development of new competencies in its units as a way of developing operations strategies. This initiative aims to ensure the governance of its processes and provide a common language for solving problems between units. It presents characteristics of a corporation where its units are rooted in a specific environment, culture, or product, with significant difficulty in mobility. Models are typically managed from the top-down manufacturing center to the units. Upon the establishment of competitive priorities, practices are shared among the units and, consequently, a growing movement of capability development. All units have the same production models, same equipment, but are not embedded in the same institutional contexts. Each unit under analysis is in a different country.

The best practices adopted in European units are followed closely in the other units. The local context is poorly considered, and the organization rarely allows significant operational changes. Generally, given the characteristics of the market, the actors in different manufacturing units are encouraged by the top management to seek an exchange of experiences and practices. They realize the level of expertise their products offer, and everyone has access to the same resource base. Consequently, the process of knowledge, technology, and expertise-sharing simplifies and aid the flow of relations. Top management supports the exchange of knowledge and drives the organization towards continuous improvement of processes and costs.

\subsection{Cross-case Analysis: Social Skill Influences}

In theory, both organizations under analysis can share capabilities: they have a rich set of skills and knowledge accumulated over the years, which should be favorable for controlling activities and address the best use of its resources (Flynn et al., 2010). However, by analyzing back and forth the evidence gathered from cases, it could 
be perceived that organizations present different conceptions of capability diffusion due to different actors' mindsets. While the current literature reinforces the technical aspects of capability diffusion (Peng et al., 2008; Wu et al.; 2010) soft skills and the social role of the individuals demonstrate to have a critical impact in the capability establishment, not constrained to the learning process itself (Nonaka, 1994; Jacobides \& Winter 2005; Ritala et al., 2015).

Actors embrace their social differently skills to support the link between individuals and fields while conducting their operations strategy and disseminating capabilities among the network. From the interaction with other actors, socially skilled actors advance the creation of common values, identity, and roots for their assumptions, which bring meaning to the narratives adopted by individuals. This search for the actor's mindset alignment is a way of promoting control and ensuring the organization's competitiveness and survival. Table 2 illustrate evidence for cross-case based on state of the field and field stability (Fligstein \& McAdam, 2012), higher common principles, the state of worthiness, the relation of worth (Boltanski \& Thevenot, 2006), power and control mechanisms (Maloni \& Benton, 2000; Crook \& Combs, 2007) and the relationship between members (Fligstein \& McAdam, 2012). Those elements offered substantial resources for building the cross-case analysis.

Our findings suggest that in Case A, fields are unstable (Fligstein, 2013). All units have their way of doing things and are quite resistant to change. They do not recognize another's positive movements and even do not share best practices or lessons learned. Differently, Company B demonstrates the achievement of more stable fields. They search for continuous improvements, generally based on other fields of experience. Because the headquarters (HQ) supports continuous knowledge-sharing, and there is clear evidence of the willingness of an organization to use and share the knowledge, less capable matured units tend to imitate more mature field behavior as a growing adaptation process.

Consequently, less capable matured units engage in a similar way of producing and controlling the quality of products and services, which generates greater confidence and a stronger position in the marketplace. From this appraisal, the first proposition of the study emerges:

Proposition 1: The diffusion of operational capabilities among units is favored if the strategic action fields are stable, as these are shown to be mimetic and open to incremental changes.

The pieces of evidence shown in Table 2 also support that socially skilled actors connect their values with organization values and deploy them within other actors (Fligstein \& McAdam, 2012). During the data collection in Company A, the researchers observed constant complaints about top management's lack of support and misalignment between units. Most of the plant managers were not aware of corporate strategy and were focused on individual outcomes. They had their perspective of what it was necessary to achieve the results and deploy this mindset among the actors of their field. If they faced any flunk, someone outside the field would be blamed for it. As Fligstein (2001), argues,

The crisis of new fields reflects the fact that stable rules of interaction have not emerged and groups are threatened with extinction. Skilled social actors will orient their actions to stabilizing their group internally and stabilizing their group's relation to other groups. It is important to note that in these situations, skilled social actors may fail. Skilled actors may be unable to build political coalitions or may be members of groups that are strong enough to enforce a local social order. (Fligstein, 2001, p. 115).

The most important feature of this finding was that social skill actors are unable to react. Since it was difficult to explain who and why someone won or lost, they preferred to preserve the identity and values, defending the field as much as possible. They did not recognize the importance of other field decisions and strategies adopted. There was no apparent movement to be open and learn from others' experiences. Instead, they were harmed by decisions and plans made by managers from other units. Team members did not welcome benchmarking and changes promoted by outside actors. In Case A, all resolutions were legitimized by the uniqueness of the sweet plant production, asset specification, or customer characteristics.

On the other hand, members of Company B demonstrated a precise alignment with the headquarters mindset, and they felt proud of being part of it. They always justified their decisions as a "German way of doing things" as an analogy of high quality and discipline. Even when HQ imposed something to be replicated among all units and, consequently, it would cause impact, and actors rarely were resistant. This mindset was perceived in several members of the field, and the same speech could be heard under various circumstances. In this organization, there was an increasing interest in sharing problems and solutions among units and at different functional levels as well. It was recognized as a way of improving their time-to-market and avoiding unnecessary costs. Proposition 2: The process of diffusion of operational capabilities among units is directly related to the perception of value by the actors in the field. If the new capability conflicts with the values and 
identity of the group, the latest operational capability tends not to stabilize in the field, regardless of the formal power exercised by the organization.

The field research was addressed in a period of critical socio-economic crisis in Brazil. Consequently, researchers could understand how actors behaved during this period and how they exploited operational capabilities to support their decisions. Uncertainty can arise in disharmonies between the worth of the individuals and, consequently, lead to controversies. Socially skilled actors have an essential role in rescuing the harmony within the field, bringing back other actors to a common world. At Company B, uncertainty was critical, and the most impactful results could be perceived in the automotive division. Members of the Brazilian unit tried to recover best practices addressed in the past, and other units supported the team in different decision-making processes to mitigate the impact on the shop floor by dismissing employees, for instance.

The social turbulence or uncertainty favors social skill in playing a pivotal role in holding local orders together (Fligstein, 2001). In Company B, socially skilled actors asked for help from other fields and deployed internally the good fortune of being attended. They counted on support from other sites, transferring technology, changing old-fashioned processes to attend their local needs. Socially skilled actors presented "uncertainty" to their field members as an opportunity of finding new ways of doing things, improving training, and promoting the challenges of 'radical changes' to the entire organization. In this way, once local members trusted the organization and relied on the organization's trajectory and previous success, they respected the new rules. They also recognized the inescapability of the decision taken and understood that, at the individual level, they were not strong enough to support the uncertainty by themselves.

Due to the instability of the field in Company A, it was possible to observe that uncertainty increased the competitiveness among units. Moreover, managers gave up process improvement strategies, training activities, and focused on downsizing teams. As Fligstein (2001, p. 177) affirms “After all, dominating groups have resources and rules on their side, and the dominated have fewer opportunities" Cost reduction was a key driver, although they did not exploit the total cost of ownership and other possible directions addressed by a sister company, for instance. Actors were resistant to change and were wholly dependent on the current system. Even if the reality were pushing actors toward change, they preferred to keep their way of solving issues. Consequently, this myopia created a bad working environment, extending the uncertainty more than necessary.

Proposition 3: "Faced with a critical moment of uncertainty, the actors can appropriate from distinct or ambiguous narratives to justify their actions, depending on the level of trust in or dependence on the system, even though these justifications do not reflect their convictions, values or even the reality itself."

With the support of a team of continuous improvement, the operational capabilities were quickly assimilated among the different manufacturing units in the Company B network. Even considering that units were spread all around the world, geographical distance (Rudberg \& Olhager, 2003), however, was not a problem for the actors. The hierarchy was clear and recognized by the fields, which brought a social order (Fligstein \& McAdam, 2012). Small conflicts emerged when local characteristics were not considered in senior leadership decision-making, but this rarely impacted the stability of the fields.

The researchers note the justification speeches comprised the logic of the "Domestic World", and the actors based themselves on the "Industrial World" rationale to justify their inefficiency in meeting the expected performance. The narratives of the actors in the field involved arguments that went back to respect for the hierarchy and the technical superiority of the manufacturing unit in Germany. It was justified as Germany was a field with greater access to resources and, consequently, they were more capable of promoting their vision of the field and strengthening its hierarchical position. On the other hand, Germany's power relation with the other fields was not established coercively, but as a referential and due to their expertise gained over time (Maloni \& Benton, 2000; Crook \& Combs, 2007). Such a narrative is tied to the logic of the "Domestic World." By launching a change in the production process to improve innovation competence, for example, the group justified the move by recognizing the quality of German operations, even though this ended up generating conflicts by changing the status quo of some of its members. However, the justification was quickly absorbed, and the field remained stable. Proposition 4: "The social actors, members of a strategic action field, tend to adopt a logic (perception of the world) that reflects the point of view of the group, and from this, the actors construct their narratives, recognize the legitimacy and justify their actions based on this logic."

The same logic of justifying the decision-making process was also perceived at Company A. They were proud of the past and their presence in the market. In some way, they tended to demonstrate a selfish behavior when refusing to share knowledge with other fields (sister companies). They possessed a self-image stronger than the actual reality presented. There was still a sense of unstructured belonging. The fields were in constant conflict for the attention of top leadership. This common behavior of being more public than others and incessant anger about being recognized legitimizes their justification for the decisions taken. In this way, Company A 
justified the field actions using the logic of "World of Fame," since the worth was derived merely from opinion and recognition, instead of facts.

Unlike Company B, what was important was the opinion of others that encouraged their pattern of work. What seemed to be positive from a marketing perspective, could be fragile for OM. Socially skilled actors imposed order through the opinion of top management and fame, no matter the impacts it might cause. The main question that remained was whether this opinion reflected the reality in the field.

\section{Conclusion and implications}

The diffusion of operational capabilities is not an easy task. Practices and routines are not enough for establishing capabilities, even though this capability is a strength of a bundle of interrelated routines (Peng et al., 2008). If one recovers to physics as an analogy, one may understand as "strength" the ability to overcome the inertia of a body by modifying its speed. However, individuals behave based on a logic that reflects the point of view of the group they are embedded in.

Our investigation demonstrated that the intention and beliefs of members are closely related to the environment itself, and the narratives of the members justified the adoption or neglect of the evolution of the practice to a more robust capability. Moreover, the findings suggest that the (in)stability of the field also has a critical role in the process of disseminating a capability. Internal crisis and uncertainty increased the competitiveness among units, which hinders any movement for improving or changing the operation, especially the willingness to incorporate a new operational capability to the business. Even though that current literature highlight that operational capabilities are specific to the firm (not to the individuals that belong to it), individuals have a significant cognitive role in this process, and some cases should not recognize the timing for change. The diffusion of the capability of the firm should be reinforced or neglected within the group based on the vision of world members might have of the field.

This paper aims to understand how do socially skilled actors contribute to the diffusion of operational capabilities among intra-organizational units. The analysis offered by this study opens an avenue of new possible researches about overcoming sharing barriers by incorporating a sociological perspective of the facts. Due to the illustrative cases, it was possible to identify new configurations that accommodate the constraints for disseminating operational capabilities within units. The study drives researchers to evaluate the other side of the coin, where conflicts are not evident, and the resistance to moving forward is based on a specific mindset of individuals and their fields (Boltanski \& Thevenot, 1999), driven by socially skilled actors.

Besides, the results suggest that individuals drive behaviors, the field they are embedded, and shared views of the world to gain a better understanding of the capabilities diffusion process. The authors encourage practitioners and future studies:

1) Match fields and visions of the world and identify possible gaps that should impact the willingness to absorbed and share operational capabilities.

2) Evaluate to what extent these configurations impact on group dynamics.

3) This study paid particular attention to the capability diffusion as a whole, and researchers shall examine if specific capability perform differently based on the worlds that actors are embedded.

4) Evaluate metrics to analyze how deep it can be disseminated and incorporated operational capabilities in an intra-organizational network.

To evaluate how do actors drive themselves in a critical moment of uncertainty, there are pieces of evidence that actors adopt an approach from ambiguous narratives for justifying their behavior. It shall be deeper explored by incorporating the human resources perspective. It seems to be suitable for evaluating the level of dependence an actor has in the system, his/her convictions and values.

This study has several limitations. Firstly, it was based on two polar case studies. This decision was essential to elucidate apparent differences between two different organizations and evaluate them through the sociological lens. Due to the need for profound exploitation of individual and group behaviors, the researchers attempt to mitigate bias in our analysis and conclusions by addressing a special effort to define clear categories, rigor, and serious data analysis, discussing every single evidence between researchers. Future studies shall advance this research, increasing sample size, different environments, and industries. 


\section{References}

Ambos, T. C., Ambos, B., \& Schlegelmilch, B. B. (2006). Learning from foreign subsidiaries: An empirical investigation of headquarters' benefits from reverse knowledge transfers. International Business Review, 15(3), 294-312. http://dx.doi.org/10.1016/j.busrev.2006.01.002.

Amason, A. C., Thompson, K. R., Hochwarter, W. A., \& Harrison, A. W. (1995). Conflict: An important dimension in successful management teams. Organizational Dynamics, 24(2), 20-35. http://dx.doi.org/10.1016/0090-2616(95)90069-1.

Amit, R., \& Schoemaker, P. J. (1993). Strategic asset and organizational rent. Strategic Management Journal, 14(1), 33-46. http:// dx.doi.org/10.1002/smj.4250140105.

Angrosino, M., \& Rosenberg, J. (2011). Observations on observation. In N. K. Denzin, \& Y. S. Lincoln, The sage handbook of qualitative research (p. 766). California: Sage Publications.

Barratt, M., Choi, T. Y., \& Li, M. (2011). Qualitative case studies in operations management: Trends, research outcomes, and, future research implications. Journal of Operations Management, 29(4), 329-342. http://dx.doi.org/10.1016/j.jom.2010.06.002.

Biazzin, C., Paiva, E. L., \& De Figueiredo, J. C. B. (2020). Operational capabilities diffusion for sustainable competitiveness: Towards an integrated framework. International Journal of Services and Operations Management, 371), 10019478. http://dx.doi.org/10.1504/ IJSOM.2020.10019478.

Björkman, 1., Stahl, G. K., \& Vaara, E. (2007). Cultural differences and capability transfer in cross-border acquisitions: The mediating roles of capability complementarity, absorptive capacity, and social integration. Journal of International Business Studies, 38(4), 658-672. http://dx.doi.org/10.1057/palgrave.jibs.8400287.

Boltanski, L., \& Thevenot, L. (1999). The sociology of critical capacity. European Journal of Social Theory, 2(3), 359-377. http://dx.doi. org/10.1177/136843199002003010.

Boltanski, L., \& Thevenot, L. (2006). On Justification: Economies of worth. New Jersey: Princeton University Press.

Bourdieu, P. (2005). 0 campo econômico. Política and Sociedade, 4(6), 15-58.

Candido, S. E. A., Côrtes, M. R., Truzzi, O. M. S., \& Sacomano Neto, M. (2018). Fields in organization studies: relational approaches? Gestão \& Produção, 25(1), 68-80. http://dx.doi.org/10.1590/0104-530x2122-16.

Candido, S. E. A., Soulé, F. V., \& Sacomano Neto, M. (2017). Power and culture in supply chains: contributions of the strategic action fields approach. Production, 27(0), 27. http://dx.doi.org/10.1590/0103-6513.213516.

Ciabuschi, F., Forsgren, M., \& Martín, O. M. (2017). Value creation at the subsidiary level: Testing the MNC headquarters parenting advantage logic. Long Range Planning, 50(1), 48-62. http://dx.doi.org/10.1016/j.lrp.2016.03.004.

Crook, R., \& Combs, J. (2007). Sources and consequences of bargaining power in supply chains. Journal of Operations Management, 25(2), 546-555. http://dx.doi.org/10.1016/j.jom.2006.05.008.

DiMaggio, P. J., \& Powell, W. W. (1983). The iron cage revisited: Institutional isomorphism and collective rationality in organizational fields. American Sociological Review, 48(2), 147-160. http://dx.doi.org/10.2307/2095101.

Dyer Junior, W. G., \& Wilkins, A. L. (1991). Better Stories, not better constructs, to generate better theory: a rejoinder to Eisenhardt. Academy of Management Review, 16(3), 613-619. http://dx.doi.org/10.5465/amr.1991.4279492.

Durkheim, E. (2002). As regras do método sociológico. São Paulo: Martin Claret.

Eisenhardt, K. (1989). Building theories from case study research. Academy of Management Review, 14(4), 532-550. http://dx.doi. org/10.5465/amr.1989.4308385.

Eisenhardt, K. M., \& Galunic, D. (2000). Coevolving - At last, a way to make synergies work. Harvard Business Review, 78, 91-101.

Emirbayer, M. (1997). Manifesto for a relational sociology 1. American Journal of Sociology, 103(2), 281-317. http://dx.doi. org/10.1086/231209.

Ferdows, K. (2012) Sharing Know-How in Global Production Networks, Fourth Doctoral Euroma Summer School, Budapest, 9-13 July [Powerpoint Slides].

Fligstein, N. (1987). The intraorganizational power struggle: Rise of finance personnel to top leadership in large corporations, 19191979. American Sociological Review, 52(1), 44-58. http://dx.doi.org/10.2307/2095391.

Fligstein, N. (1990). The transformation of corporate control. Cambridge, MA: Harvard University Press.

Fligstein, N. (2001). Social Skill and the Theory of Fields. Sociological Theory, 19(2), 105-125. http://dx.doi.org/10.1111/0735-2751.00132.

Fligstein, N. (2013). Understanding stability and change in fields. Research in Organizational Behavior, 33, 39-51. http://dx.doi. org/10.1016/j.riob.2013.10.005.

Fligstein, N., \& McAdam, D. (2012). A theory of fields. New York: Oxford University Press. http://dx.doi.org/10.1093/acprof:0 so/9780199859948.001.0001.

Flynn, B., Wu, S. J., \& Melnyk, S. (2010). Operational capabilities: Hidden in plain view. Business Horizons, 53(3), 247-256. http:// dx.doi.org/10.1016/j.bushor.2010.01.001.

Grant, R. (1996). Toward a knowledge-based theory of the firm. Strategic Management Journal, 17(S2), 109-122. http://dx.doi. org/10.1002/smj.4250171110.

Grant, R. M. (2000). R.M. Grant Shifts in the world economy: The driver of knowledge management. In: C. Despres \& D. Chauvel (Eds.), Knowledge horizons: The present and the promise of knowledge management. Oxford: Butterworth-Heineman.

Grössler, A., \& Grübner, A. (2006). An Empirical Model of the relationship between manufacturing capabilities. International Journal of Operations \& Production Management, 5(5), 458-485. http://dx.doi.org/10.1108/01443570610659865.

Guillén, M. F. (1994). Models of management: Work, authority, and organization in a comparative perspective. Chicago: University of Chicago Press.

Helfat, C. E., \& Winter, S. G. (2011). Untangling dynamic and operational capabilities: Strategy for the (N)ever-changing world. Strategic Management Journal, 32(11), 1243-1250. http://dx.doi.org/10.1002/smj.955. 
Jacobides, M. G., \& Winter, S. G. (2005). The co-evolution of capabilities and transaction costs: Explaining the institutional structure of production. Strategic Management Journal, 26(5), 395-413. http://dx.doi.org/10.1002/smj.460.

Jones, R. A., Jimmieson, N. L., \& Griffiths, A. (2005). The impact of organizational culture and reshaping capabilities on change implementation success: The mediating role of readiness for change. Journal of Management Studies, 42(2), 361-386. http://dx.doi. org/10.1111/j.1467-6486.2005.00500.x.

Jost, J. T., \& Hunyady, O. (2005). Antecedents and Consequences of System-Justifying Ideologies. Current Directions in Psychological Science, 14(5), 260-265. http://dx.doi.org/10.1111/j.0963-7214.2005.00377.x.

Katsikopoulos, K. V., \& Gigerenzer, G. (2013). Behavioral operations management: A blind spot and a research program. The Journal of Supply Chain Management, 49(1), 3-7. http://dx.doi.org/10.1111/j.1745-493x.2012.03285.x.

Katz, D., \& Kahn, R. L. (1978). The social psychology of organizations (Vol. 2). New York: Wiley.

Kogut, B., \& Zander, U. (1992). Knowledge of the firm, combinative capabilities, and the replication of technology. Organization Science, 3(3), 383-397. http://dx.doi.org/10.1287/orsc.3.3.383.

Lin, S. L., \& Hsieh, A. T. (2010). International strategy implementation: Roles of subsidiaries, operational capabilities, and procedural justice. Journal of Business Research, 63(1), 52-59. http://dx.doi.org/10.1016/j.jbusres.2008.11.008.

Lindgreen, A., Hingley, M. K., Grant, D. B., \& Morgan, R. E. (2012). Value in business and industrial marketing: Past, present, and future. Industrial Marketing Management, 41(1), 207-214. http://dx.doi.org/10.1016/j.indmarman.2011.11.025.

Maloni, M., \& Benton, W. (2000). Power influences in the supply chain. Journal of Business Logistics, $21(1), 49$.

Martin, J. L. (2003). What ls field theory? American Journal of Sociology, 109(1), 1-49. http://dx.doi.org/10.1086/375201.

Menor, L. J., Kristal, M. M., \& Rosenzweig, E. D. (2007). Examining the influence of operational intelectual capital on capabilities and performance. Manufacturing \& Service Operations Management : M\& SOM, 9(4), 559-578. http://dx.doi.org/10.1287/msom.1060.0131.

Meredith, J. (1998). Building operations management theory through case and field research. Journal of Operations Management, 16(4), 441-454. http://dx.doi.org/10.1016/S0272-6963(98)00023-0.

Meyer, J. W., \& Rowan, B. (1977). Institutionalized organizations: Formal structure as myth and ceremony. American Journal of Sociology, 83(2), 340-363. http://dx.doi.org/10.1086/226550.

Miles, M. B., Huberman, A., \& Saldaña, J. (2014). Qualitative data analysis - A methods source book. California: Sage.

Morgan, G. (2005). Paradigmas, metáforas e resolução de quebra-cabeças na teoria das organizações. RAE-Revista de Administração de Empresas, 45(1), 58-71.

Muchiri, M., Shahid, S., \& Ayoko, O. (2019). And now for something completely different: Reframing social processes of leadership theory using positive organizational behavior. Journal of Management \& Organization, 25(3), 370-373. http://dx.doi.org/10.1017/ jmo.2019.33.

Nonaka, 1. (1994). A dynamic theory of organizational knowledge creation. Organization Science, 5(1), 14-37. http://dx.doi.org/10.1287/ orsc.5.1.14.

Norman, P. M. (2004). Knowledge acquisition, knowledge loss, and satisfaction in high technology alliances. Journal of Business Research, 576), 610-619. http://dx.doi.org/10.1016/S0148-2963(02)00395-8.

Olsen, T. H., \& Solstad, E. (2017). Changes in the power balance of institutional logics: Middle managers' responses. Journal of Management \& Organization, 26(4) 1-4. http://dx.doi.org/10.1017/jmo.2017.72.

Pavlou, P., \& El Sawy, O. (2011). Understanding the elusive black box of dynamic capabilities. Decision Sciences, 42(1), 239-273. http:// dx.doi.org/10.1111/j.1540-5915.2010.00287.x.

Peng, D. X., Schoroeder, R., \& Sha, R. (2008). Linking routines to operations capabilities: A new perspective. Journal of Operations Management, 26(6), 730-748. http://dx.doi.org/10.1016/j.jom.2007.11.001.

Prahalad, C. K., \& Hamel, G. (1990). The Core competence of the corporation. Harvard Business Review, 68(3): 79-91.

Ranft, A. L., \& Lord, M. D. (2002). Acquiring new technologies and capabilities: A grounded model of acquisition implementation. Organization Science, 13(4), 420-441. http://dx.doi.org/10.1287/orsc.13.4.420.2952.

Ritala, P., Olander, H., Michailova, S., \& Husted, K. (2015). Knowledge sharing, knowledge leaking, and relative innovation performance: An empirical study. Technovation, 35, 22-31. http://dx.doi.org/10.1016/j.technovation.2014.07.011.

Rowley, J. (2012). Conducting research interviews. Management Research Review, 35(3-4), 260-271. http://dx.doi.org/10.1108/01409171211210154.

Rudberg, M., \& Olhager, J. (2003). Manufacturing networks and supply chains: An operations strategy perspective. Omega, 31(1), $29-39$. http://dx.doi.org/10.1016/S0305-0483(02)00063-4.

Sako, M. (2004). Supplier development at Honda, Nissan, and Toyota: comparative case studies of organizational capability enhancement. Industrial and Corporate Change, 13(2), 281-308. http://dx.doi.org/10.1093/icc/dth012.

Schoenherr, T., \& Narasimhan, R. (2012). The fit between capabilities and priorities and its impact on performance improvement: revisiting and extending the theory of production competence. International Journal of Production Research, 50(14), 3755-3775. http://dx.doi.org/10.1080/00207543.2011.588266.

Silverman, D. (2006). Interpreting qualitative data: methods for analyzing talk, text, and interaction. London: Sage.

Spring, M., Hughes, A., Mason, K., \& McCaffrey, P. (2017). Creating a competitive edge: A new relationship between operations management and industrial policy. Journal of Operations Management, 49(1), 6-19. http://dx.doi.org/10.1016/j.jom.2016.12.003.

Swidler, A. (1986). Culture in Action: Symbols and Strategies. American Sociological Review, 51(2), 273-286. http://dx.doi.org/10.2307/2095521.

Tsai, W., \& Ghoshal, S. (1998). Social capital and value creation: The role of intrafirm networks. Academy of Management Journal, 41(4), 464-476.

Tsai, W. (2002). Social structure of "coopetition" within a multiunit organization: Coordination, competition, and intraorganizational knowledge sharing. Organization Science, 13(2), 179-190. http://dx.doi.org/10.1287/orsc.13.2.179.536. 
Van Wijk, R., Jansen, J. J., \& Lyles, M. A. (2008). Inter-and intra-organizational knowledge transfer: a meta-analytic review and assessment of its antecedents and consequences. Journal of Management Studies, 45(4), 830-853. http://dx.doi.org/10.1111/j.14676486.2008.00771.x.

Winter, S. G., \& Szulanski, G. (2001). Replication as strategy. Organization Science, 12(6), 730-743. http://dx.doi.org/10.1287/ orsc.12.6.730.10084.

Wu, S. J., Melnyk, S. A., \& Flynn, B. B. (2010). Operational Capabilities: The Secret Ingredient. Decision Sciences, 41(4), 721-754. http:// dx.doi.org/10.1111/j.1540-5915.2010.00294.x.

Zander, U., \& Kogut, B. (1995). Knowledge and the speed of the transfer and imitation of organizational capabilities: An empirical test. Organization Science, 6(1), 76-92. http://dx.doi.org/10.1287/orsc.6.1.76. 


\section{Appendix A - Research instrument - Semi-structured interview}

\section{Pre-interview}

- Ice-breaking - talk about amenities: world and Brazilian economic situation, organization and market dynamics, some breaking news, etc.

- Listen to respondent background and experience.

\section{Research presentation}

- Researcher presentation. Present the research objectives and why the respondent was selected to participate.

- Explain operations capabilities by using the kitchen analogy (Wu et al., 2010). Ask the respondent to exemplify the analogy in the context of the organization he/she works to check if it was clear.

- Ask the respondent to identify an existing operational capability in his/her organization. Examples.

3. Research content

Capability development and dissemination mechanisms

- Explain how this capability was developed, its origins? Where does it come from? From another site? From customer need or market? From an employee suggestion?

- What were the factors that you think were important to develop this capability? (positive and negative)

- The capabilities already established in one site can be shared with another plant of your corporation? How does the respondent perceive it? Identify pieces of evidence that the respondent saw in the organization he/she works or worked

Field dynamics

- Check how decisions are made and to what extent each site can manage its operations (autonomy, HQ-subsidiary, the relation of worth and power)

- How is the relationship between plants? Communication channels?

- Does the capability developed in one plant can impact the external environment? (the community, city, etc.)?

- To what extent does the environment that the company is embedded can impact operational capability dissemination?

- Did you recognize any employee or a group of employees that can facilitate or not the deployment of changes in your organization? Who? (Match the names/groups with other respondents statements later)

- Is that any other factor that impact the process of capability dissemination that was not presented and you think it could be critical to the context of this research

\section{Wrap-up}

- Thank the respondent for his/her contribution. Reinforce the confidentiality terms. Ask for indications of other potential respondents to this theme (Snow-ball) 